\title{
Loss and damage from the double blow of flood and drought in Mozambique
}

\section{Ange-Benjamin Brida* and Tom Owiyo}

United Nations Economic Commission for Africa,

Special Initiatives Division,

African Climate Policy Centre,

P.O. Box 3001, Addis Ababa, Ethiopia

E-mail: abrida@uneca.org

E-mail: angebrida@gmail.com

E-mail: towiyo@uneca.org

*Corresponding author

\section{Youba Sokona}

\section{The South Centre,}

CP 228, 1211 Geneva 19, Switzerland

E-mail: ysokona@gmail.com

\begin{abstract}
Loss and damage associated with the adverse effects of climate variability and climate change is currently an important topic being discussed under the United Nations Framework Convention on Climate Change. This study investigated loss and damage from floods and droughts among rural households living near the Limpopo, Zambezi and Save rivers in Mozambique. We used a questionnaire survey $(n=303)$ and qualitative research tools. The study showed that farmers in the research areas were caught between two evils. In the uplands, conditions for agriculture are extremely poor and crop yields are low; moreover, farmers face considerable risk of crop failure when drought hits. In the lowlands, close to the river, soil and water conditions are more favourable, but these areas experience frequent floods. Evidence from this study shows that farmers in the research areas are severely affected by both floods and droughts, and their capacity to cope and adapt is limited. With very little livelihood diversification and poor access to markets, crop failures translate almost directly into severe food insecurity among the population.
\end{abstract}

Keywords: loss and damage; flood; drought; climate change; climate variability; coping; agriculture; livelihood; resettlement; Mozambique.

Reference to this paper should be made as follows: Brida, A-B., Owiyo, T. and Sokona, Y. (2013) 'Loss and damage from the double blow of flood and drought in Mozambique', Int. J. Global Warming, Vol. 5, No. 4, pp.514-531.

Biographical notes: Ange-Benjamin Brida is a Research Fellow at the African Climate Policy Centre (ACPC). His research interests include hydrology, climate change impacts, vulnerability and risk assessment.

Tom Owiyo is a Senior Climate Change and Agriculture Specialist at the African Climate Policy Centre (ACPC). 
Youba Sokona is co-Chair of the IPCC Working Group III and former Coordinator of the African Climate Policy Centre (ACPC). He recently joined the South Centre as a Special Advisor on Sustainable Development.

\section{Introduction}

The adverse effects of climate change and climate variability on the environment and on socio-economic systems are increasingly creating major challenges for communities and governments. Addressing these challenges is also adding to the difficulties of development, particularly in the least developed countries of Africa. The United Nations Framework Convention on Climate Change (UNFCCC), whose objective is to help countries cooperatively achieve "stabilization of greenhouse gas concentrations in the atmosphere at a level that would prevent dangerous anthropogenic interference with the climate system", established a work programme on loss and damage under the Cancun Adaptation Framework during the 16th Conference of the Parties (COP16). The aim of the programme is to consider approaches to addressing loss and damage associated with climate change impacts in developing countries that are particularly vulnerable to the adverse effects of climate change. ${ }^{2}$

As current mitigation efforts to reduce greenhouse gas concentrations in the atmosphere and funding for adaptation measures are not enough, there are growing calls for governments to prepare communities for serious havoc that may be wreaked by climate change. Among the emerging issues in this regard is the issue of 'loss and damage'. Loss and damage is a new concept in climate change research and there is as yet no commonly accepted definition. Different views have emerged with regard to the framing of loss and damage and institutional mechanisms to address loss and damage. Most of the parties concur to the idea that loss and damage is a 'residual risk' even if the circumstances leading to this risk are not fully agreed. It does, however, entail some of the principles embedded in the UNFCCC - such as the attainment of Article 2 and the common, but different, responsibilities of Parties in contributing to responses to climate change. For the purpose of this research, we used a working definition explaining loss and damage as the "negative effects of climate variability and climate change that people have not been able to cope with or adapt to" (Warner et al., 2012). This definition highlights the importance of community vulnerability to particular climate threats. According to the United Nations International Strategy for Disaster Risk Reduction (UNISDR, 2009) vulnerability refers to "the characteristics and circumstances of a community, system or asset that make it susceptible to the damaging effects of a hazard". In other words, vulnerability can be seen as "the propensity or predisposition to be adversely affected" (IPCC, 2012). In order to understand loss and damage, it is essential to understand how vulnerable communities are exposed to and affected by climate stressors.

Reflecting on loss and damage also revives the debate around community-based adaptation and the limits to top-down adaptation planning strategies. Smith (1997) discussed the opportunity of setting priorities for adaptation in the context of climate 
change while discussions were opened around the possibility for Africa to adapt to climate change in its particular context (Sokona and Denton, 2001). Eight years later, Adger et al. (2005) outlined a set of normative evaluation criteria for judging the success of adaptations at different scales, arguing that elements of effectiveness, efficiency, equity and legitimacy are important in judging success in terms of the sustainability of development pathways into an uncertain future. Thomas and Twyman (2005) also discussed the equity and justice dimensions of adaptation in communities that are dependent upon natural resources. Recent development in climate science has established a range of expected impacts from human-induced climate change: i.e., ice melt, sea-level rise, heavy rainfall cyclone, floods and droughts (IPCC, 2007). Nevertheless, the link between climate change on one hand and social vulnerability or resilience on the other has not yet been well explored. This is because the methods used for studying social systems tend to be qualitative, e.g., ethnography and participant observation, and data from these methods may not fit comfortably with the quantitative approaches prevalent in other social and natural sciences on climate change (Adger et al., 2013). Therefore, science and policy thinking open up a space for a new paradigm reshaped around interactions between climate impacts and society (cf. Moser, 2010; Warner et al., 2012). This study is a contribution to efforts to bridge the divide between science and policy in addressing the social dimensions of climate change. It specifically addresses the way in which the impact of floods and droughts on livelihoods leads to loss and damage for rural households in those zones of southern and central Mozambique that are predominantly dependent on maize cultivation for their livelihoods.

\section{Research area}

Mozambique, located on the eastern coast of southern Africa, is one of the least developing countries in this region. With its $2,700 \mathrm{~km}$ coastline, the country is already experiencing the devastating effects of the increasing frequency of cyclones, floods and droughts on agricultural livelihoods in rural areas (FAO, 2012). Mozambique is hit by one disaster a year on average and ranks third on weather-related damage, following Bangladesh and Ethiopia (Buys et al., 2007; Artur, 2011). Indeed, the country is noted as being disaster prone and among the most vulnerable to climate change and climate-related disasters (Osbahr et al., 2008; Patt and Schröter, 2008; Eriksen and Silva, 2009; Hahn et al., 2009; INGC, 2009; Artur, 2011; de Sherbinin et al., 2011; Artur and Hilhorst, 2012; Notenbaert et al., 2012). For these reasons, Mozambique has received considerable attention and support for the implementation of a climate change adaptation programme (World Bank, 2000; Foley, 2007; World Food Program, 2007; FAO, 2012). As such, it provides a useful area in which to explore loss and damage in the context of social vulnerabilities and resilience.

Mozambique can be divided into three main zones vulnerable to different natural hazards resulting in different impacts. Evidence from observations suggests an increase in the number of natural disasters in the country during the past three decades (INGC, 2009). The centre of the country is more prone to floods, tropical cyclones and 
epidemics, followed by the south and the north. The south of the country, with its tropical dry savannah climate, is more prone to drought than the centre or north, which are dominated respectively by a tropical rainy climate and a moderately humid climate modified by altitude. In terms of the number of people affected, floods and drought are the most serious natural disasters in the country. ${ }^{3}$

Mozambique's three main rivers, namely the Limpopo, the Save and the Zambezi, play a critical role in the occurrence of the double blow of flood and drought affecting the most vulnerable communities living along their banks (Figure 1). Therefore, in order to investigate loss and damage from flood and drought, four study sites were selected in four districts - Chibuto, Mabote, Caia and Mopeia, which are crossed by those three rivers. The characteristics of study sites are shown in Table 1.

Table 1 Characteristics of research sites, by district

\begin{tabular}{lcccc}
\hline District & $\begin{array}{c}\text { District } \\
\text { population }\end{array}$ & Province & River & $\begin{array}{c}\text { Households } \\
\text { interviewed }\end{array}$ \\
\hline Chibuto & 191,682 & Gaza & Limpopo & 57 \\
Mabote & 44,733 & Inhambane & Save & 60 \\
Caia & 115,612 & Sofala & Zambezi & 31 \\
Mopeia & 115,291 & Zambezi & Zambezi & 155 \\
\hline
\end{tabular}

Figure 1 Research area (see online version for colours)

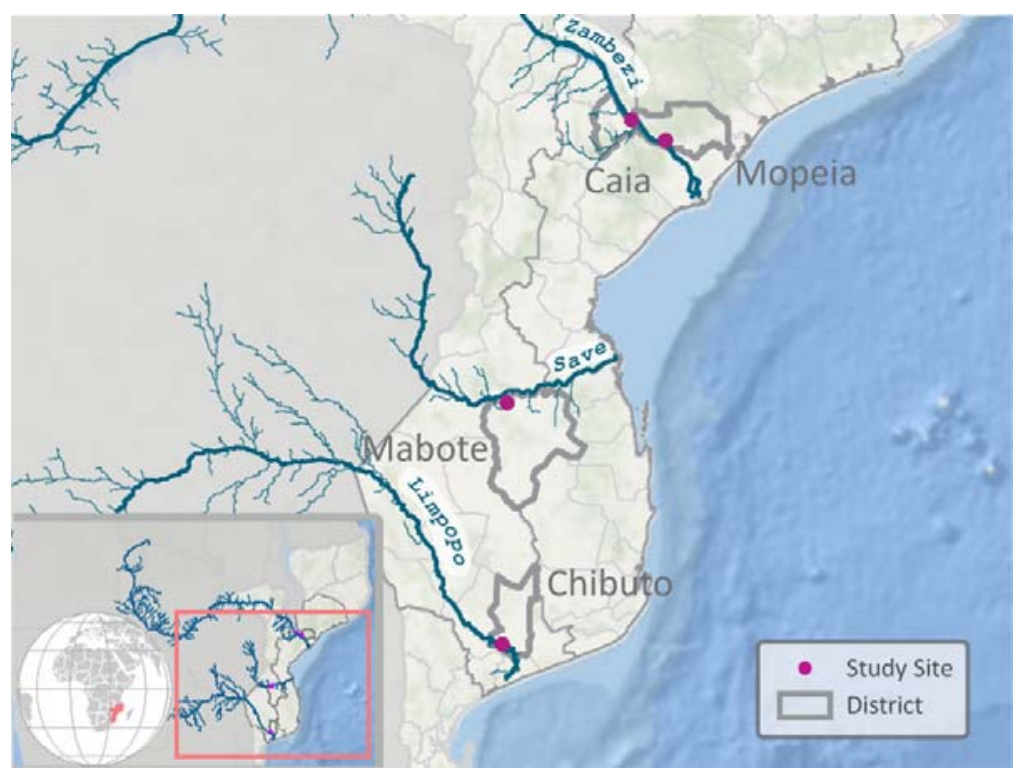

Source: Map created by the Center for International Earth Science Information Network (CIESIN) 


\section{Methodology}

The study generated original data using a systematic research frame to specifically address the issue of loss and damage from various climate stressors. Primary and secondary data was collected during the fieldwork, using both qualitative and quantitative methods, including: household survey, focus group discussions and key informant interviews (Warner et al., 2012).

\subsection{Household survey}

Questionnaire interviews were held with over 300 households in four districts. Households were selected using a random number generator tool applied to lists collected from local chiefs. The questionnaire ${ }^{4}$ allowed us to address in a systematic way issues such as the general socio-economic and demographic characteristics of the households, impacts of flood and drought, coping and adaptation strategies, loss and damage associated with inability to cope and adapt effectively, and community ideas about policy options to reduce impacts and loss and damage.

\subsection{Focus group discussions}

Focus group discussions were organised to ask participants open questions that required in-depth answers, which helped elucidate the dynamics between key concepts of this research (i.e., climate stressors, impacts, vulnerability, coping, and loss and damage). The focus group discussions complemented the household survey, as they gathered qualitative information on how particular floods and droughts can lead to loss and damage among local population.

\subsection{Key informant interviews}

Key informants were interviewed to obtain information that could not easily be obtained from focus group discussions or the household survey. The key informant interviews were particularly useful for gathering information about the activities of government agencies and international organisations.

\section{Results}

\subsection{Survey overview: predominance of agricultural livelihood system}

In total, 303 households were interviewed during the fieldwork. The average household size was 6.14 , with a dependency ratio of 1.26 , suggesting that one household member engaged in income generating activities has to support at least one other family member. The education level of household heads in the research areas was very low, with only $11.2 \%$ having a tertiary or secondary education. Almost half (43.1\%) of the household heads had never been to school, and $44.1 \%$ had only attended primary school. 
Table 2 Survey overview

\begin{tabular}{|c|c|}
\hline \multicolumn{2}{|c|}{ General characteristics } \\
\hline Household in survey & 303 \\
\hline Average household size & 6.1 \\
\hline Dependency ratio (average) & 1.26 \\
\hline \multirow[t]{3}{*}{ Religion (\%) } & Christian (84.9) \\
\hline & Muslim (0.3) \\
\hline & Atheist (14.5) \\
\hline \multicolumn{2}{|c|}{ Age, gender and education characteristics } \\
\hline \multicolumn{2}{|l|}{ Age (average) } \\
\hline Respondent & 42 \\
\hline Household head & 45 \\
\hline Female household head (\%) & 38 \\
\hline Female respondent $(\%)$ & 56 \\
\hline \multicolumn{2}{|l|}{ Education of household head (\%) } \\
\hline None & 43.1 \\
\hline Literacy & 1.3 \\
\hline Primary & 44.1 \\
\hline Secondary & 10.5 \\
\hline Tertiary & 0.7 \\
\hline Other & 0.3 \\
\hline \multicolumn{2}{|c|}{ Households economic characteristics (\%) } \\
\hline Crop cultivation & 100 \\
\hline Livestock keeping & 71.7 \\
\hline Fishing & 30.4 \\
\hline Non-farm activity & 13.2 \\
\hline Own land (\%) & 100 \\
\hline Size cultivated land (hectare) & 2.17 \\
\hline Irrigated land (\%) & 5.6 \\
\hline \multicolumn{2}{|l|}{ Main purpose of crop production (\%) } \\
\hline Household consumption & 98.3 \\
\hline Sale & 1.3 \\
\hline Crop sale (US\$) per annum & 45 US\$ \\
\hline Annual crop sale is $0(\%)$ & 67.0 \\
\hline Average household income (US\$) & 462 US\$ \\
\hline Proportion from crop sales (\%) & 9.7 \\
\hline \multicolumn{2}{|l|}{ Trend in crop production } \\
\hline Decrease $(\%)$ & 93.1 \\
\hline Remained the same (\%) & 3.0 \\
\hline Increase $(\%)$ & 3.9 \\
\hline
\end{tabular}


Crop cultivation is the most important economic activity (practised by $100 \%$ of households surveyed), followed by livestock keeping (71.7\%) and fishing (30.4\%). Non-farm activities represent only $13 \%$ of livelihood activity in research areas. Maize is the most important crop, although crop diversification is widely practised - sorghum, cassava, millet, beans and pumpkin as well as lettuce, cabbage, tomatoes and other vegetables are also cultivated (Figure 2). For the majority of households, crop production has fallen $(93.1 \%)$; only $3 \%$ had observed no clear rise or fall in crop production and $3.9 \%$ reported an increase. The characteristics of households in our study areas suggest they are among the poorest in the country. Livelihood systems in the research areas are dominated by farming activities; the low percentage of non-farm activity illustrates the very limited extent of livelihood diversification.

Figure 2 Main crop cultivated (see online version for colours)

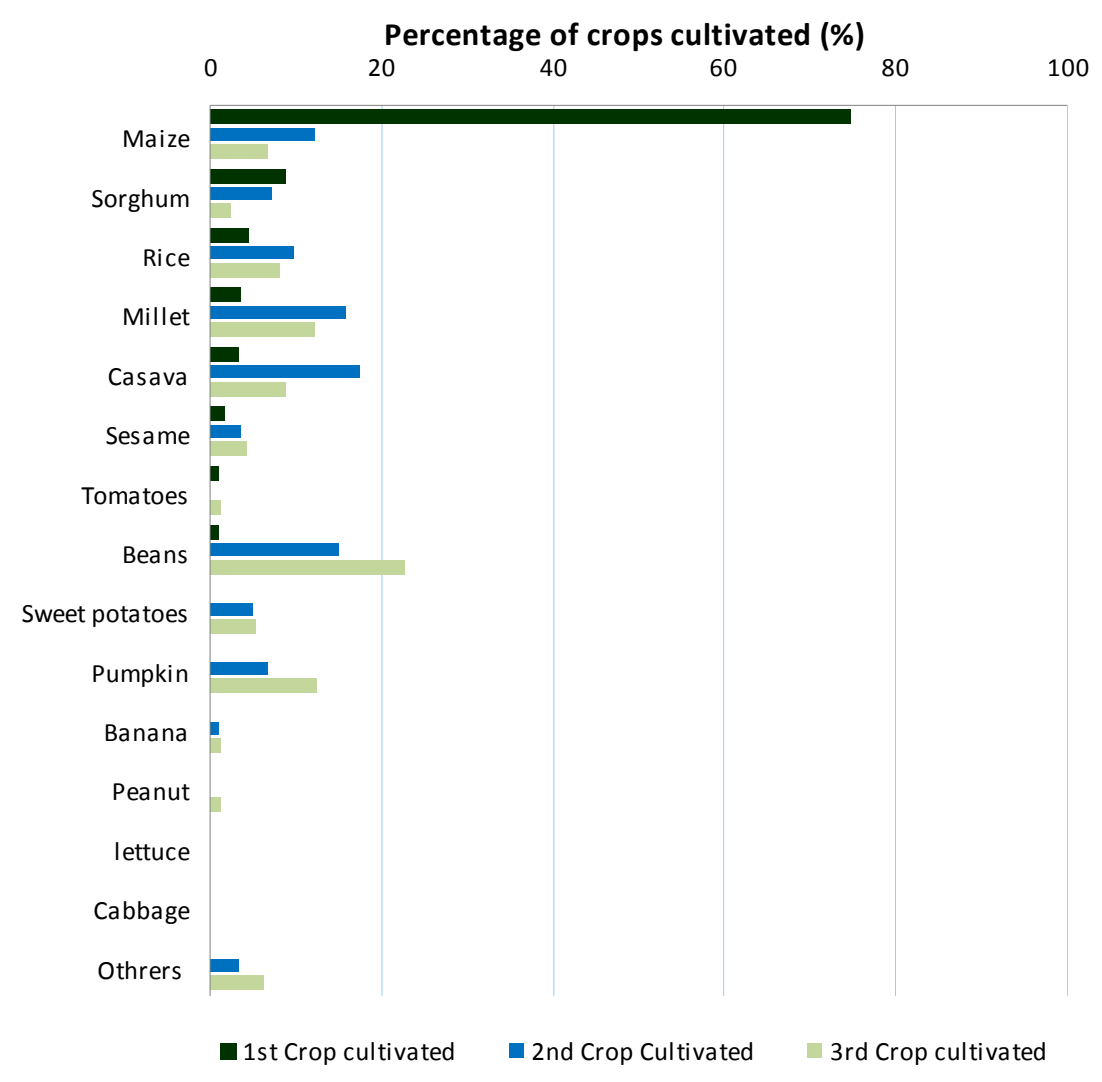

\subsection{Occurrence of flood and drought}

Communities report alternating floods and droughts over the last two decades, which correlates with the major disasters that occurred at the beginning the century (Figure 3). The survey result show that the first decade of the century was dominated by flood, particularly the 2000/01 flooding, followed by a period of drought with a peak year in 2005. The next year appeared to be less dry, forming a transition period before a second devastating flooding period. 
Figure 3 Flood and drought events (see online version for colours)

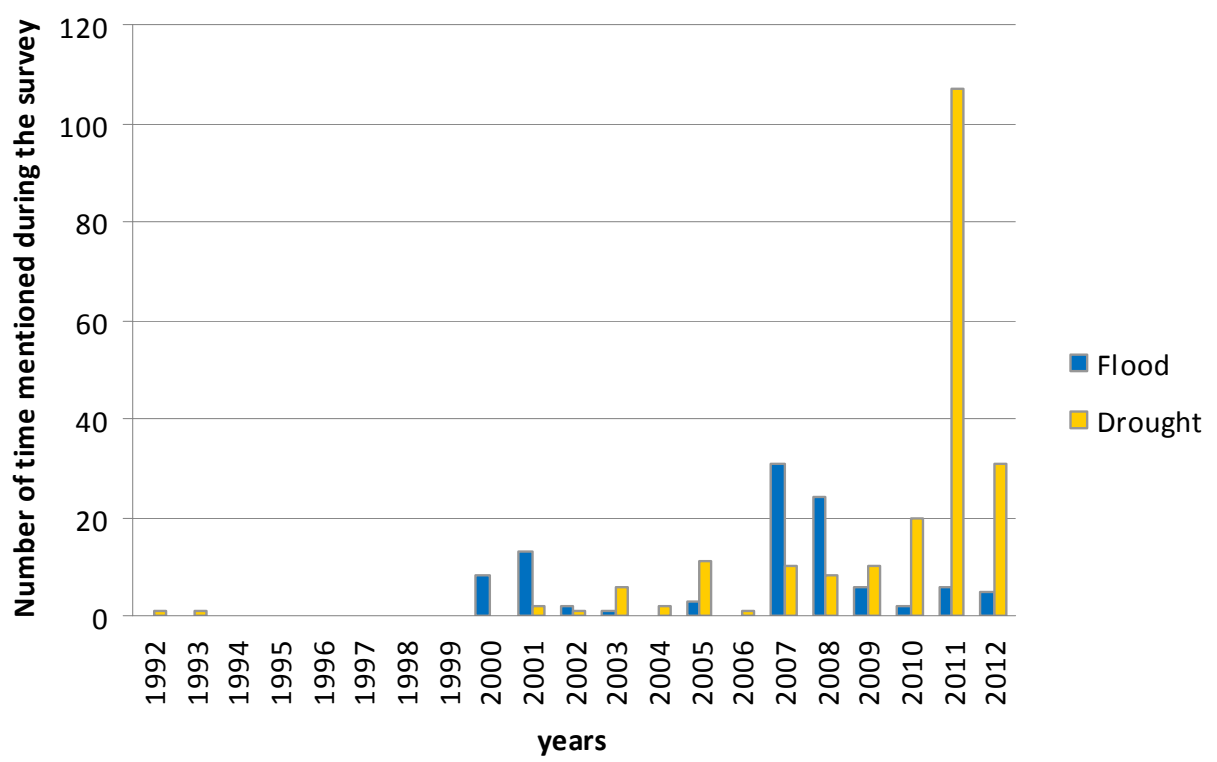

The second period of floods principally affected the Zambezi delta (cf. Artur, 2011). This delta, which includes the districts of Caia and Mopeia, was flooded in 2007, 2008 and 2009 as reported during our qualitative and quantitative data collection. The following years are dominated by droughts, the majority occurring during the period 2009 to 2012 , just after the second major resettlement programme undertaken by the government. It seems that communities perceive drought as the most catastrophic event after being resettled in uplands. This is the trigger for farmers to return to lowlands, increasing again their exposure to flood risk.

Despite alternating flood and drought, it is clear that both events happened almost each year with different magnitude and intensity. The resettlement of communities from lowland to upland areas in response to devastating flood reduced flood risks among communities to some extent, but at the same time considerably increased their exposure to drought risks.

\subsection{Impact of flood and drought among communities}

Flood and drought severely affected the households surveyed, with $86 \%$ of households who experienced a particular flood $(n=92)$ saying they had been severely affected, and $84 \%$ of households who experienced a particular drought $(n=211)$ saying the same. It is clear that drought impacted the most (2/3) rural households compared to flood $(1 / 3)$, although the impact of the latter is nevertheless not inconsequential in terms of severity. Both flood and drought severely impacted more than $80 \%$ of households.

The impact of the double blow from flood and drought can be estimated to affect more than $99 \%$ of rural households, based on our survey data (Table 3). Impacts of flood and drought on different livelihoods are also severe. The most important livelihoods affected are crop production (100\%), foods prices (83\%), livestock $(35 \%)$, fishing $(23 \%)$ and houses/assets $(12 \%)$. Both flood and drought affect crop production, but drought has 
more negative impacts on fishing than flood does (30\% versus $10 \%)$, while flood has more negative impacts on houses/assets than drought (37\% versus $1.4 \%$ ). Another indicator of the difficulties for rural communities in coping with drought compared to flood is the impact of drought on food prices and livestock ( $85 \%$ and $37 \%$ ), which is slightly higher than in the case of floods ( $79 \%$ and $31 \%)$. This analysis set the scene for understanding the core of our conception of loss and damage, which is the inability to effectively cope with the impact of climate stressors. Indeed, given the overarching vulnerability of communities in the survey area and the severity of impacts, it is conceivable that residual impacts which cannot be absorbed will result in loss and damage.

Table 3 Impacts of flood and drought on household and livelihood

\begin{tabular}{lccc}
\hline Impacts & Flood (\%) & Drought (\%) & Total (\%) \\
\hline Impacts on household & 1 & & \\
Not affected & 13 & 0,5 & 0.6 \\
Moderate & 86 & 16 & 15.2 \\
Severely affected & & 83.5 & 84.2 \\
Impacts on livelihood & 100 & & \\
Crop production & 79 & 100 & 100 \\
Food prices & 31 & 85 & 83 \\
Livestock & 10 & 37 & 35 \\
Fishing & 37 & 30 & 23 \\
Houses/properties & 1.4 & 12 \\
\hline
\end{tabular}

Figure 4 Impacts of floods and droughts (see online version for colours)

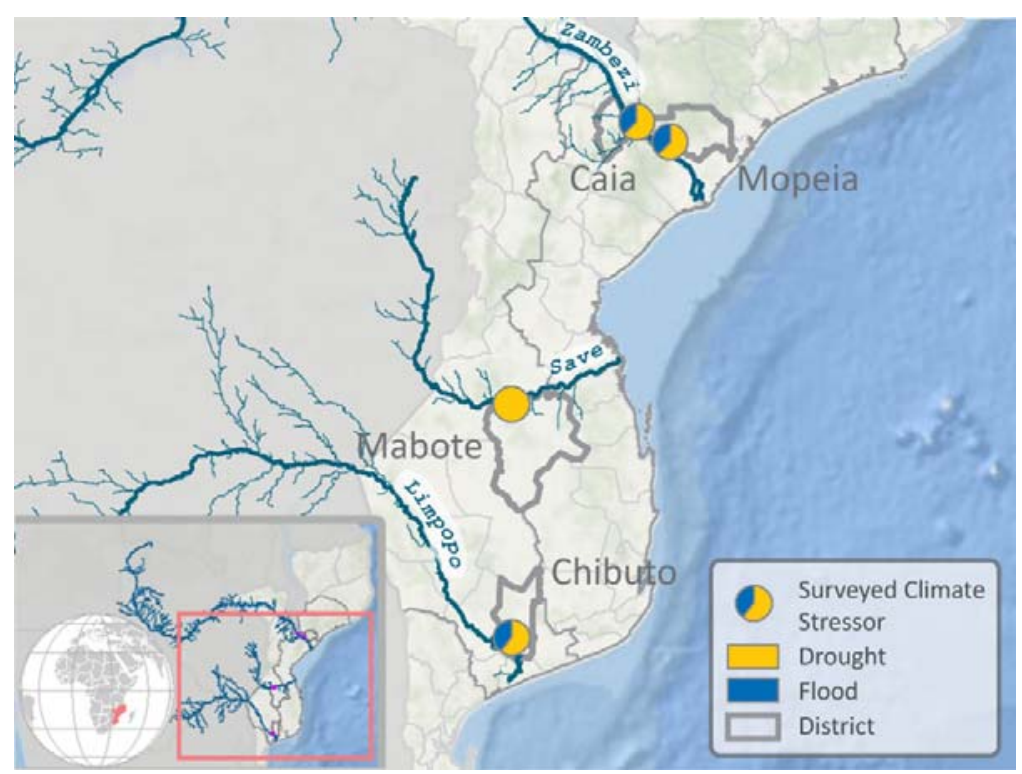

Source: Map created by the CIESIN 
The impacts of the double blow of flood and drought on rural households have the potential to cause serious loss and damage if adequate coping strategies are not put in place. It is obvious that interventions such as resettlement have increased communities' exposure to drought, and findings from this study show that exposure to flood and drought risks is still a reality (Figure 4). That may be due to the fact that the farm-based livelihoods of those households leave them little choice but to farm the lower flood-prone areas or the higher drylands.

\subsection{Household coping strategies}

Despite the 'powerlessness discourse' often used at international level when a disaster occurs, rural communities in Mozambique have developed several coping strategies to deal with flood and drought. These include: looking for extra income, selling assets, relying on help from others, relying on help from organisations, and undertaking other types of coping strategies (Figure 5).

Figure 5 (a) Summary of finding in Mozambique: flood (b) summary of finding in Mozambique: drought (see online version for colours)

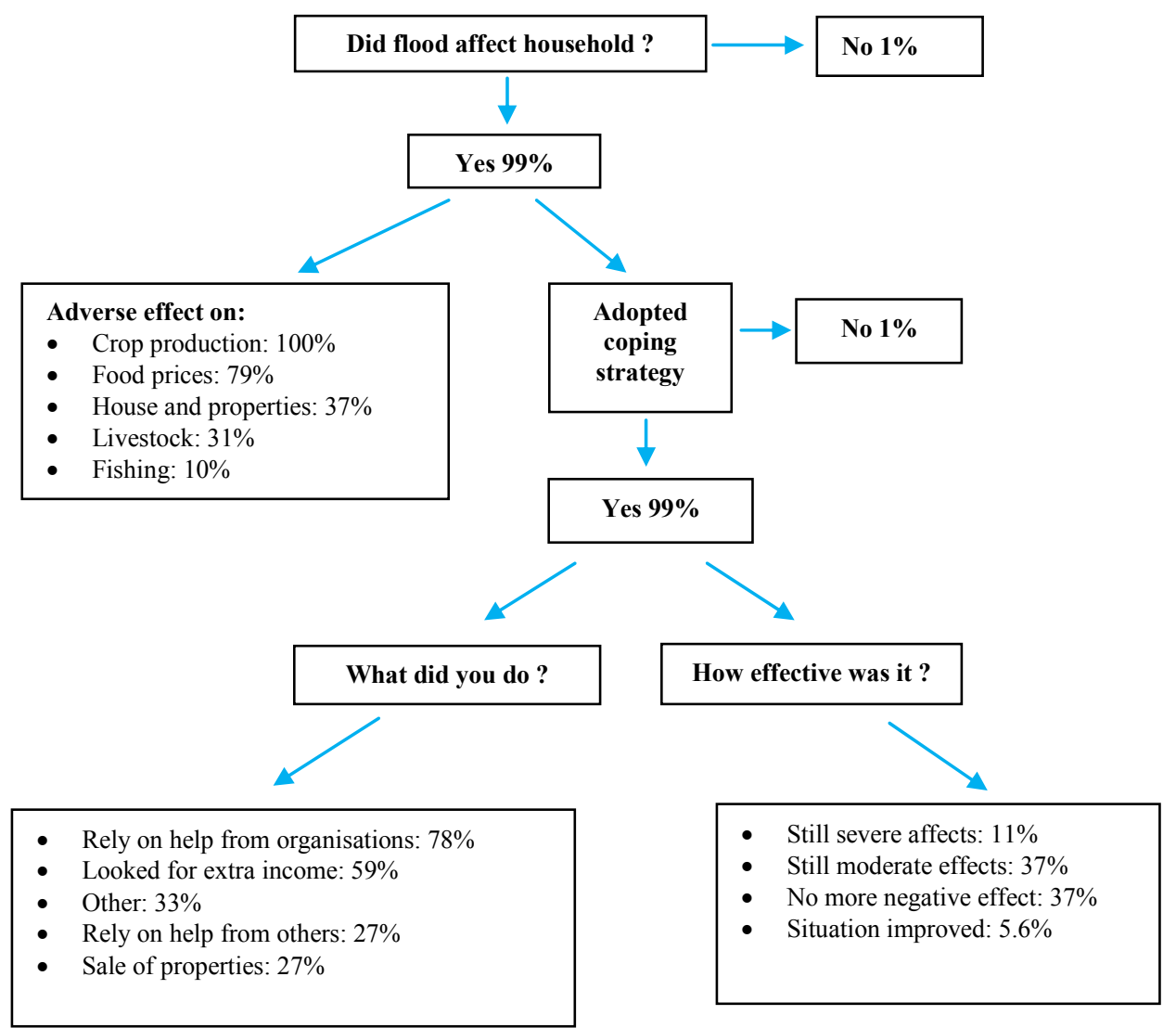


Figure 5 (a) Summary of finding in Mozambique: flood (b) summary of finding in Mozambique: drought (continued) (see online version for colours)

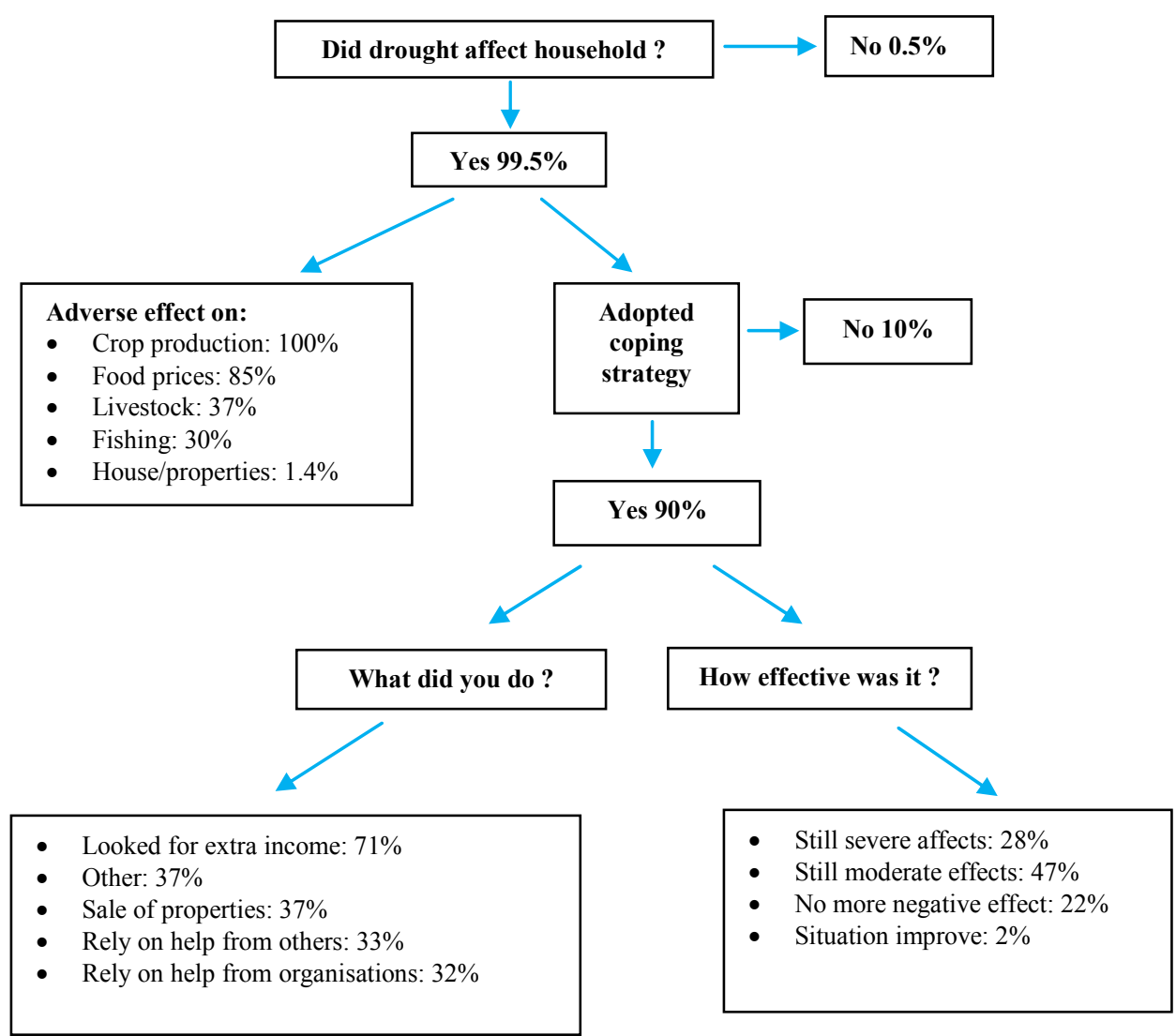

(b)

\subsubsection{Looking for extra income}

Looking for extra income is a prime coping strategy for rural households in Mozambique. This is explained by the fact that crops are severely affected by flood or drought, and therefore cash is needed to buy food. This strategy was undertaken by about $70 \%$ and $60 \%$ of households in reaction to drought and flood respectively. Asked about action to generate extra income, respondents mentioned either the intensification of existing activities or engagement in new income-generating activities. These generally concern fishing, petty trade and gathering wild products (e.g., firewood, grass and reed). Producing handicrafts, traditional alcohol and charcoal, and undertaking farm labour, are other income-generating activities that people engaged in to deal with drought and flood impacts. 


\subsubsection{Selling assets}

Generally, this involves selling livestock and in limited cases productive assets, clothing or domestic cookware. This strategy has an erosive impact on household assets. It would generally be the last option in the case of flood, because households could be helped by aid, but would happen earlier in case of drought, when aid may not be so quickly forthcoming. This highlights once again how droughts are badly experienced by rural communities.

\subsubsection{Relying on help from others}

Around $30 \%$ of the households relied on help from relatives or friends to cope. However, in many cases, the people they relied on were also affected by the drought or flood and their capacity to support was limited. Many respondents said that they were hesitant to call on their social network for support after a particular drought or flood, partly because they realised that there are limits to the support they can ask. In that sense, relying on help from other people is also erosive. Another explanation why relying on support from other people was not a preferred coping strategy is social embarrassment. Many household heads were hesitant about asking others for support because it revealed their inability to feed their household, which would reduce their social status.

\subsubsection{Relying on help from organisations}

This includes help from the government and from non-governmental national and international organisations. Mostly envisaged as a last option in the case of drought, this coping strategy is a first choice in the case of floods, emphasising our earlier remarks on aid flow. Because slow-onset droughts are difficult to characterise and predict, it is more difficult to plan and react to them. Therefore, communities are less likely to receive very much aid.

\subsubsection{Undertaking other types of coping strategies}

Farmers mentioned a range of activities - known locally as ganho-ganho - that also serve as coping strategies. People might labour for the better-off in exchange for cash, food or anything that could help to improve their family's life. Some households mentioned consuming wild fruits, taking on a new farm in lower or upper land to expand areas of cultivation, growing short-cycle and drought-resistant crops such as cassava and millet, agreeing to resettle permanently in the resettlement centres, relying more on social capital and aid, or migrating to other areas of the country or to the Republic of South Africa.

\subsection{Loss and damage from the double blow of flood and drought}

Despite efforts to cope with flood and drought, the majority of households surveyed reported that they are still experiencing negative impacts from flood and drought [Figures 5(a) and 5(b)]. This suggests that their coping strategies are not effective enough. The loss and damage incurred by communities as a result of floods and droughts come from impacts on agricultural livelihoods in general and crop production in particular. In lowland areas, crops will suffer serious damage from flooding - leading most of the time to a total loss of harvests. Some communities fear losing their traditional 
way of life in lowland areas because of the government's intensive resettlement programme. In the upland areas where they have been resettled, communities in the research areas are struggling to produce under very dry conditions. Their crops often fail and yields are very low. The natural option for those who have no access to viable non-farm activities due to low levels of education, is to go back to the lowland areas where crop yields are higher. An alternative to the conflicting views of rural communities and government, would be a strategy supporting households to have farms in both uplands and lowlands. Despite the fact that this option would be a good trade-off between government and community priorities, loss and damage from the double blow of flood and drought would not necessarily be abated. Indeed, there is a risk-spreading element in this strategy, with reduced risk of total crop failure in both upland and lowland farms. Due to this risk spreading one could expect that losses would become more frequent, but less severe. However, farmers in the area also indicated that nowadays, due to increasingly erratic rainfall, in one year, they can have a farm washed away by flood in the lowland and experience a complete crop failure in uplands due to drought. The magnitude of the risks that farmers in the research areas face is such that there are no easy solutions. Only a very balanced set of measures in different sectors, such as investments that make dryland farming more viable, can substantially improve the situation for farmers in the area.

There is a clear indication that loss and damage from the climate stressors studied in this research is a tangible reality for rural communities. Despite adopting coping strategies, almost $50 \%$ of households reported that they still suffered the negative effects of flood, while $77 \%$ indicated that their coping strategies did not prevent adverse effects of drought (Table 4). These numbers include the households who could not take any action due to their inability to cope. The cost of inaction, as well as the cost of coping strategies, represent significant loss and damage to communities. For example, losing all production due to flood, being forced to exhaust assets or social capital because of flood or drought, spending more time travelling between uplands and lowlands result in considerable quantitative and qualitative loss and damage for rural households.

Table 4 Core indicators of loss and damage from flood and drought ( $\%$ of households)

\begin{tabular}{lccccc}
\hline & $(a)$ & $(b)$ & $(c)$ & $(d)$ & $(e)$ \\
Climate-stressor & $\begin{array}{c}\text { Experienced } \\
\text { stressor (\%) }\end{array}$ & $\begin{array}{c}\text { Experienced } \\
\text { impact }(\%)\end{array}$ & $\begin{array}{c}\text { Adopted } \\
\text { measures (\%) }\end{array}$ & $\begin{array}{c}\text { Impact despite } \\
\text { measures (\%) }\end{array}$ & $\begin{array}{c}\text { Loss and } \\
\text { damage (\%) }\end{array}$ \\
\hline Flood & 100 & 99 & 99 & 48 & 48 \\
Drought & 100 & 100 & 90 & 75 & 77 \\
\hline
\end{tabular}

Notes: Column (b) is a proportion of the households in column (a); column (c) is a proportion of those in column (b); and column (d) is a proportion of those in column $(\mathrm{c})$. 'Loss and damage' in column $(\mathrm{e})$ is calculated as: $\mathrm{e}=(\mathrm{a} * \mathrm{~b} * \mathrm{c} * \mathrm{~d})+$ $((1-c) * a * b)$, where the letters stand for the percentages in the corresponding columns. In words, it is the proportion of the whole survey population that experienced adverse effects despite adopting measures to cope or adapt plus those who were affected but who did not adopt any measures in response (Warner and van der Geest, 2013).

The impact of extreme droughts and floods on people's health and homes was also mentioned. In the southern districts - Chibuto and Mabote - the consumption of roots from the Limpopo and wild fruits such as Momordica balsamina (commonly called cacana), as well as drinking water from the Save and the Limpopo, have had serious 
impacts on people's health. For example, cases of diarrhoea and swelling of lower and upper limbs have been reported. In the central districts of Caia and Mopeia, flooding had a devastating impact on homes and livestock. All these impacts have a negative effect on household income and savings, reducing their coping abilities and increasing their vulnerability to extreme floods and droughts - leading to serious loss and damage.

\section{Discussion: shaping responses in the context of climate-related loss and damage}

Loss and damage from flood and drought occurs due to an inability to effectively cope with these climate stressors. Responding to floods by resettlement in upland areas exposed households to drought, while having farms in both uplands and lowlands did not eliminate flood and drought risks. This particular measure requires even more efforts to craft livelihoods between the two areas. Crop production will be severely affected and food security will become a critical problem, as community livelihoods are predominantly reliant on agriculture. During the major flood and drought events reported in this study, crop production was severely affected. Maize, the most important crop grown by households, was seriously compromised, as it is not drought resistant nor can it withstand heavy flooding. The dependency of rural households on maize for their staple food (called chima) meant that they experienced serious food insecurity. This particular vulnerability is emphasised in households' socio-economic profile derived from our data. In addition, low levels of education and lack of alternative sources of income, make households more vulnerable - locking them into ineffective practices such as ganho-ganho, which was widely reported by respondents and other studies (e.g., Osbahr et al., 2008).

Evidence from farmers gathered for this study highlights erratic climate conditions, with alternating floods and droughts. Understanding social transformations in the context of climate variability and climate change could help improve adaptation interventions at community level aimed at livelihood diversification. Relying on farming activities is the most accessible option for local farmers, but it is very sensitive to climate stresses. With low education levels, household heads face difficulties in migrating to the city or finding alternative opportunities in resettlements. Moving beyond the earlier study by Stal (2011), this study highlights the fact that resettlement is not the perfect option to deal with current and future impacts of environmental change in Mozambique. While we should acknowledge that it did help significantly to reduce loss of life due to flooding, we also need to recognise the difficulties faced by resettled communities. Patt and Schröter (2008) also underscored differences in perceptions of the seriousness of climate risks, and the potential consequences of adaptive measures proposed by policymakers to famers, based on a case study of a resettlement programme in Mozambique. Their study highlighted the need for an active dialogue across stakeholder groups as a necessary condition for formulating policies that could be successfully implemented. Moreover, adaptation to climate change has been described as a process closely related to historical and ongoing social and institutional processes (Artur and Hilhorst, 2012). More emphasis is given to this view by Adger et al. (2013) in their analysis of the cultural dimension of climate change adaptation, showing how culture mediates change in the environment and societies, elucidating shortcomings in contemporary adaptation policy. 
Our research also underlines this fundamental need for a more holistic and innovative approach in planning adaptation and thereby reducing, rather than increasing, loss and damage. So far, resettlement from lower to upper land and the strategy of having farms in both areas have not been fully effective in reducing the impacts of floods and droughts. In a context of projected future climate change that will have impact on extremes events (cf. IPCC, 2012), this strategy could increase food insecurity as a result of loss and damage from the double blow of flood and drought. In this context, assessing vulnerability using information from various sources, including community perceptions and coping strategies, is key. Attempts to derive a vulnerability index that includes information from communities has been proposed (Kienberger, 2010; Notenbaert et al., 2012). However, vulnerability - and thereby loss and damage resulting from inability of communities to cope with climate stressors - depends also on the global economic context. Unfavourable market conditions could seriously hinder efforts towards income diversification. Market relations are not favourable to smallholders and as drought impacts intensify due to resettlements in upland areas, the use of improved agricultural technologies could be seriously hindered and smallholder farmers could be locked into activities that barely secure their economic survival, thus endangering their long-term response capacity (Eriksen and Silva, 2009; Cunguara and Darnhofer, 2010). This was also one of the striking findings from our research - suggesting that loss and damage that jeopardises household food security is accelerated by poor access to markets as well as poor livelihood diversification and lack of skills and capital.

\section{Conclusions}

The climate in Mozambique has become more variable, increasing the occurrence of climate stressors such as floods and drought. Rural households in the research areas are highly vulnerable to the double blow of flood and drought because of livelihoods based primarily on farming activities, their lack of capital, insufficient skills and education, and unfavourable market conditions. Measures undertaken by communities to cope with the adverse impacts of flood and drought were often not sufficient to avoid loss and damage, especially in the case of drought. Agriculture that is mostly rainfed and directed largely towards household consumption was severely impacted. Therefore, in the context of projected climatic changes and increases in climate variability, food security in those areas is at risk. Lack of food will constitute the principal manifestation of loss and damage in the study areas in Mozambique.

Our main policy recommendations to address loss and damage include:

- Strengthening existing attempts to increase adaptive capacity, such as through diversification of livelihood activities. The research community, policymakers, practitioners and communities need to join hands and come up with well coordinated and planned actions to address vulnerability and loss and damage at community level.

- $\quad$ Linking science, policy and practice is a major challenge. In the context of least-developed countries, learning from the experience of disaster management will be critical and fundamental to inform the loss and damage discussion. Climate experts, policymakers and practitioners need to revisit risk reduction, risk retention 
and risk transfer tools in the context of loss and damage based on experiences from vulnerable countries like Mozambique.

- Creating a global institutional framework to address loss and damage with adequate mechanisms to create benefits for smallholder farmers in vulnerable countries.

\section{Acknowledgements}

The authors would like to thank the following organisations for their support and contributions to the implementation of this research: The United Nations Economic Commission for Africa, African Climate Policy Centre (UNECA-ACPC); The United Nations University, Institute for Environment and Human Security (UNU-EHS); The International Livestock Research Institute in Mozambique (ILRI-Mozambique); The National Institute for Agricultural Research of Mozambique (IIAM); and The International Livestock Research Institute in Kenya (Headquarters ILRI-Kenya) acting through the CGIAR research program on Climate Change, Agriculture and Food Security (CCAFS) regional program for eastern Africa.

\section{References}

Adger, W.N., Arnell, N.W. and Tompkins, E.L. (2005) 'Successful adaptation to climate change across scales', Global Environmental Change, Vol. 15, No. 2, pp.77-86.

Adger, W.N., Barnett, J., Brown, K., Marshall, N. and O’Brien, K. (2013) 'Cultural dimensions of climate change impacts and adaptation', Nature Clim. Change, Vol. 3, No. 2, pp.112-117.

Artur, L. (2011) Continuities in Crisis. Everyday Practices of Disaster Response in Climate Change Adaptation in Mozambique, PhD thesis, Wageningen University, Wageningen, NL.

Artur, L. and Hilhorst, D. (2012) 'Everyday realities of climate change adaptation in Mozambique', Global Environmental Change, Vol. 22, No. 2, pp.529-536.

Buys, P., Deichmann, U., Meisner, C., That, T. and Wheeler, D. (2007) Country Stakes in Climate Change Negotiations: Two Dimensions of Vulnerability, World Bank, Washington, DC, USA.

Cunguara, B. and Darnhofer, I. (2010) 'Assessing the impact of improved agricultural technologies on household income in rural Mozambique’, Food Policy, Vol. 36, No. 3, pp.378-390.

de Sherbinin, A., Warner, K. and Charles, E. (2011) 'Causalities of climate change: shifts in rainfall patterns and shorelines will lead to mass migrations on a scale never before seen', Scientific American Magazine, Environment \& Sustainability, Feature Articles, 10 January, pp.32-39.

Eriksen, S. and Silva, J.A. (2009) 'The vulnerability context of a savannah area in Mozambique: household drought coping strategies and responses to economic change', Environmental Science \& Policy, Vol. 12, No. 1, pp.33-52.

Foley, C. (2007) Mozambique: A Case Study in the Role of the Affected State in Humanitarian Action, Overseas Development Institute (ODI), London, UK.

Food and Agriculture Organization (FAO) (2012) Adaptation to Climate Change in Semi-arid Environments: Experience and Lessons from Mozambique, Environment and Natural Management Series, FOA, Rome, Italy.

Hahn, M.B., Riederer, A.M. and Foster, S.O. (2009) 'The livelihood vulnerability index: a pragmatic approach to assessing risks from climate variability and change - a case study in Mozambique', Global Environmental Change, Vol. 19, No. 1, pp.74-88.

Instituto Nacional de Gestão de Calamidades (INGC) (2009) Study on the Impact of Climate Change on Disaster Risk in Mozambique: Synthesis Report, INGC, Maputo. 
Intergovernmental Panel on Climate Change (IPCC) (2007) Climate Change 2007: Synthesis Report. Contribution of Working Groups I, II and III to the Fourth Assessment Report of the Intergovernmental Panel on Climate Change, Core Writing Team, Pachauri, R.K and Reisinger, A. (Eds.), IPCC, Geneva, Switzerland, 104p.

Intergovernmental Panel on Climate Change (IPCC) (2012) Managing the Risks of Extreme Events and Disasters to Advance Climate Change Adaptation. A Special Report of Working Groups I and II of the Intergovernmental Panel on Climate Change IPCC, Cambridge University Press, Cambridge, UK, and New York, NY, USA.

Kienberger, S. (2010) Spatial Vulnerability Assessment: Methodology for the Community and District Level Applied to Floods in Búzi, Mozambique, $\mathrm{PhD}$ thesis, Paris-London University. Salzburg, Germany.

Moser, S.C. (2010) 'Now more than ever: the need for more societally relevant research on vulnerability and adaptation to climate change', Applied Geography, Vol. 30, No. 4, pp.464-474.

Notenbaert, A., Karanja, S., Herrero, M., Felisberto, M. and Moyo, S. (2012) 'Derivation of a household-level vulnerability index for empirically testing measures of adaptive capacity and vulnerability', Regional Environmental Change, Vol. 13, No. 2, pp.459-470.

Osbahr, H., Twyman, C., Adger, W.N. and Thomas, D.S.G. (2008) 'Effective livelihood adaptation to climate change disturbance: scale dimensions of practice in Mozambique', Geoforum, Vol. 39, No. 6, pp.1951-1964.

Patt, A.G. and Schröter D. (2008) 'Perceptions of climate risk in Mozambique: implications for the success of adaptation strategies', Global Environmental Change, Vol. 18, No. 3, pp.458-467.

Smith, J.B. (1997) 'Setting priorities for adapting to climate change', Global Environmental Change, Vol. 7, No. 3, pp.251-264.

Sokona, Y. and Denton, F. (2001) 'Climate change impacts: can Africa cope with the challenges?', Climate Policy, Vol. 1, No. 1, pp.117-123.

Stal, M. (2011) 'Flooding and relocation: the Zambezi River Valley in Mozambique', International Migration, Vol. 49, No. S1, pp.125-145.

Thomas, D.S.G. and Twyman, C. (2005) 'Equity and justice in climate change adaptation amongst natural-resource-dependent societies', Global Environmental Change, Vol. 15, No. 2, pp.115-124.

United Nations International Strategy for Disaster Risk Reduction (UNISDR) (2009) 2009 UNISDR Terminology on Disaster Risk Reduction, UNISDR, Geneva, Switzerland.

Warner, K. and van der Geest, K. (2013) 'Loss and damage from climate change: local-level evidence from nine vulnerable countries', International Journal of Global Warming, this issue.

Warner, K., van der Geest, K., Kreft, S., Huq, S., Harmeling, S., Koen, K. and de Sherbinin, A. (2012) Evidence from the Frontlines of Climate Change: Loss and Damage to Communities Despite Coping and Adaptation, Loss and Damage in Vulnerable Countries Initiative, Policy Report, Report No. 9, United Nations University Institute for Environment and Human Security, Bonn.

World Bank (2000) A Preliminary Assessment of Damage from the Flood and Cyclone Emergency of February-March 2000, The World Bank, Washington, DC, USA.

World Food Program (2007) Mozambique Post-Emergency Report, WFP, Rome.

\section{Notes}

1 United Nations Framework Convention on Climate Change, Article 2.

2 UNFCCC, Decision 1/CP.16, paragraphs 25-29. 
3 'EM-DAT: The OFDA/CRED International Disaster Database, Université catholique de Louvain, Brussels' Data version: v11.08.

4 More information on the research tools, such as questionnaire structure and design, can be found on the loss and damage initiative website (http://www.lossanddamage.net/empiricalresearch), and in the synthesis report by Warner et al. (2012), which provides more detail on the methodology used in this study. The checklist for focus group discussions was derived from the open questions of the questionnaire. 